\title{
Chronic Kidney Disease, Dyslipidemia, and Atherosclerosis
}

\author{
Tetsuo Shoji ${ }^{1}$, Takaaki Abe ${ }^{2}$, Hiroshi Matsuo ${ }^{3}$, Genshi Egusa ${ }^{4}$, Yoshimitsu Yamasaki $^{5}$, Naoki Kashihara ${ }^{6}$, \\ Kohji Shirai ${ }^{7}$ and Atsunori Kashiwagi ${ }^{8}$ for Committee of Renal and Peripheral Arteries, Japan Atherosclerosis \\ Society
}

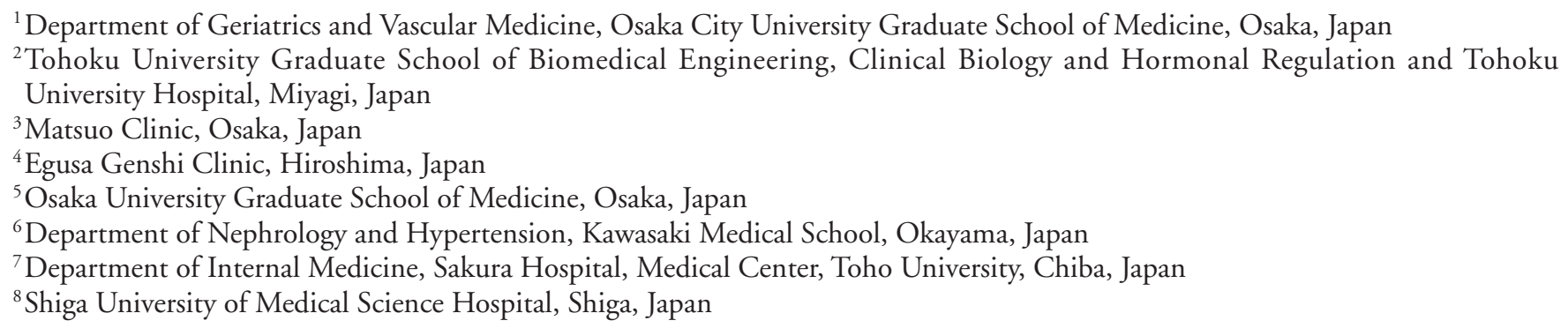

Patients with chronic kidney disease (CKD) are at an increased risk not only for end-stage kidney disease (ESKD) but also for cardiovascular disease (CVD). In this review article, we summarize the current evidence of CKD as a high-risk condition for CVD based on reports from Japan and other countries to draw attention to the close clinical association between CKD and CVD. Several epidemiologic studies have shown that the presence of CKD and reduced renal function are independent predictors of CVD also in Japan. According to a post-hoc analysis of CASE-J, the power of CKD as a predictor of CVD is as strong as diabetes mellitus and a previous history of ischemic heart disease. $\mathrm{CKD}$ worsens classical risk factors including hypertension and dyslipidemia, and dyslipidemia is associated with increased thickness and stiffness of large arteries independent of major confounders. A post-hoc analysis of MEGA indicates that lipid-lowering therapy with statins reduces the risk of CVD, and that it appears to be more efficacious in patients with than without CKD. These reports from Japan and other countries suggest that CKD should be regarded as a high-risk condition comparable to diabetes mellitus, and that strict control of dyslipidemia would be beneficial in preventing $\mathrm{CVD}$, at least early stages of CKD.

J Atheroscler Thromb, 2012; 19:299-315.

Key words; Chronic kidney disease (CKD), Cardiovascular disease (CVD), Atherosclerosis, Dyslipidemia

\section{Introduction}

Statistics indicate a steady increase in the number of patients with end-stage kidney disease (ESKD) needing renal replacement therapy including dialysis. According to the preliminary report by the Japanese Society for Dialysis Therapy (JSDT) ${ }^{1)}$, 290675 people

Current address for correspondence: Tetsuo Shoji, Department of Geriatrics and Vascular Medicine, Osaka City University Graduate School of Medicine, 1-4-3, Asahi-machi, Abeno-ku, Osaka 545-8585, Japan

E-mail: t-shoji@med.osaka-cu.ac.jp

Received: July 19, 2011

Accepted for publication: September 30, 2011 were on regular dialysis treatment in Japan at the end of 2009. Because patients with ESKD have an extremely high risk for death from cardiovascular disease $(\mathrm{CVD})^{2)}$, long-term and repeated hemodialysis treatment was previously considered as one of the major causes of the increased CVD risk ${ }^{3)}$; however, the presence of microalbuminuria is an independent predictor of $\mathrm{CVD}^{4)}$, and the risk for CVD increases in a stepwise manner during the course of progressive loss of renal function ${ }^{5}$. Thus, chronic kidney disease (CKD), rather than dialysis treatment itself, is now considered a high-risk condition for $\mathrm{CVD}^{6}$.

Such recognition has generated clinical practice guidelines especially for those with $\mathrm{CKD}$, such as the 
Table 1. Definition and classification of CKD by KDIGO (2005) ${ }^{14)}$

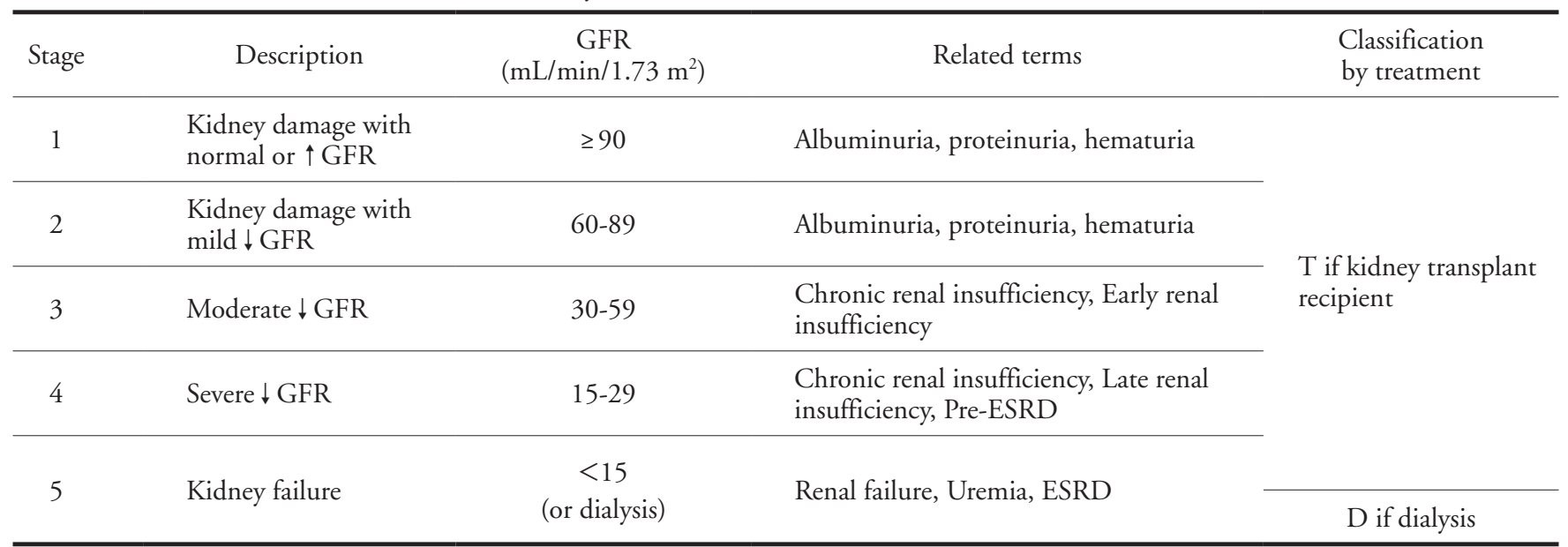

KDIGO has recently published a revised version of the definition and classification of $\mathrm{CKD}^{15}$ ) as mentioned in the text.

Abbreviations: GFR, glomerular filtration rate; ESRD, end-stage renal disease; KDIGO, Kidney Disease: Improving Global Outcome.

European Best Practice Guidelines (EBPG) ${ }^{7)}$ and the Clinical Practice Guidelines by the National Kidney Foundation (NKF) Kidney Disease Outcome Quality Initiative $(\mathrm{K} / \mathrm{DOQI})^{8)}$ in USA. Recently, the Japanese Society of Nephrology (JSN) published the "Clinical Practice Guidebook for the Diagnosis and Treatment of Chronic Kidney Disease 2007"9) and "Evidencebased Clinical Practice Guidelines for the treatment of CKD 2009"10) to help all categories of health care providers who take care of CKD patients. Generally, these clinical practice guidelines recommend strict control of risk factors for CVD, including dyslipidemia; however, the current 2007 version of the "Clinical Practice Guidelines for the Prevention of Atherosclerotic Disease" by the Japan Atherosclerosis Society $(\mathrm{JAS})^{11)}$ does not mention the elevated risk of CVD in patients with $\mathrm{CKD}$, although patients with diabetes mellitus are considered an especially high-risk subgroup in whom strict control of low-density lipoprotein cholesterol (LDL-C) is recommended.

The purpose of this article is to summarize the evidence from Japan and other countries that CKD is an important risk factor for CVD. Also, we review the role of dyslipidemia in the elevated CVD risk in CKD. Comparison of the above clinical practice guidelines will help to determine how to manage dyslipidemia in CKD.

\section{Definition, Natural History and Clinical Significance of CKD}

$\mathrm{CKD}$ is defined as either kidney damage or a glomerular filtration rate (GFR) $<60 \mathrm{~mL} / \mathrm{min} / \mathrm{m}^{2}$ for more than three months ${ }^{9,12)}$. Kidney damage is defined as pathologic abnormalities or markers of damage, including abnormalities in blood or urine tests or imaging studies. Estimated GFR (eGFR) can be calculated by formulas that are based on the serum creatinine concentration, age, and gender, for specific ethnic groups. JSN established the eGFR formula for Japanese ${ }^{13)}$. CKD is further divided into 5 stages based on the presence of albuminuria or proteinuria and the reduction of $\mathrm{GFR}^{14)}$ (Table 1). According to this classification system, dialysis patients with ESKD are diagnosed as CKD stage 5D. Also, the definition of $\mathrm{CKD}$ is used irrespective of the diagnosis of kidney disease. This simple definition of CKD enables us to deal with etiologically different kidney diseases, as well as dialysis patients and kidney transplant recipients, using the same platform. In addition, this has further facilitated clinical and epidemiological research.

Kidney Disease: Improving Global Outcome (KDIGO) has recently published the revised version of the staging system of $\mathrm{CKD}^{15)}$. In the new definition, CKD stages are defined by the combination of GFR (G1 through G5) and albuminuria (A1 through A3). In addition, previous CKD stage 3 (eGFR 30-59 $\mathrm{mL} / \mathrm{min} / 1.73 \mathrm{~m}^{2}$ ) is divided into G3a (eGFR $45-59$ $\mathrm{mL} / \mathrm{min} / 1.73 \mathrm{~m}^{2}$ ) and G3b (eGFR $30-44 \mathrm{~mL} / \mathrm{min} /$ $1.73 \mathrm{~m}^{2}$ ); however, no change is made in the cut-off levels of GFR $<60 \mathrm{~mL} / \mathrm{min} / 1.73 \mathrm{~m}^{2}$ or the urinary albumin to creatinine ratio $>30 \mathrm{mg} / \mathrm{g}$ in diagnosing CKD.

Fig. 1 depicts the conceptual natural history of CKD. The risk for developing CVD increases as the stage of $\mathrm{CKD}$ advances; therefore, the $\mathrm{CKD}$ stages 


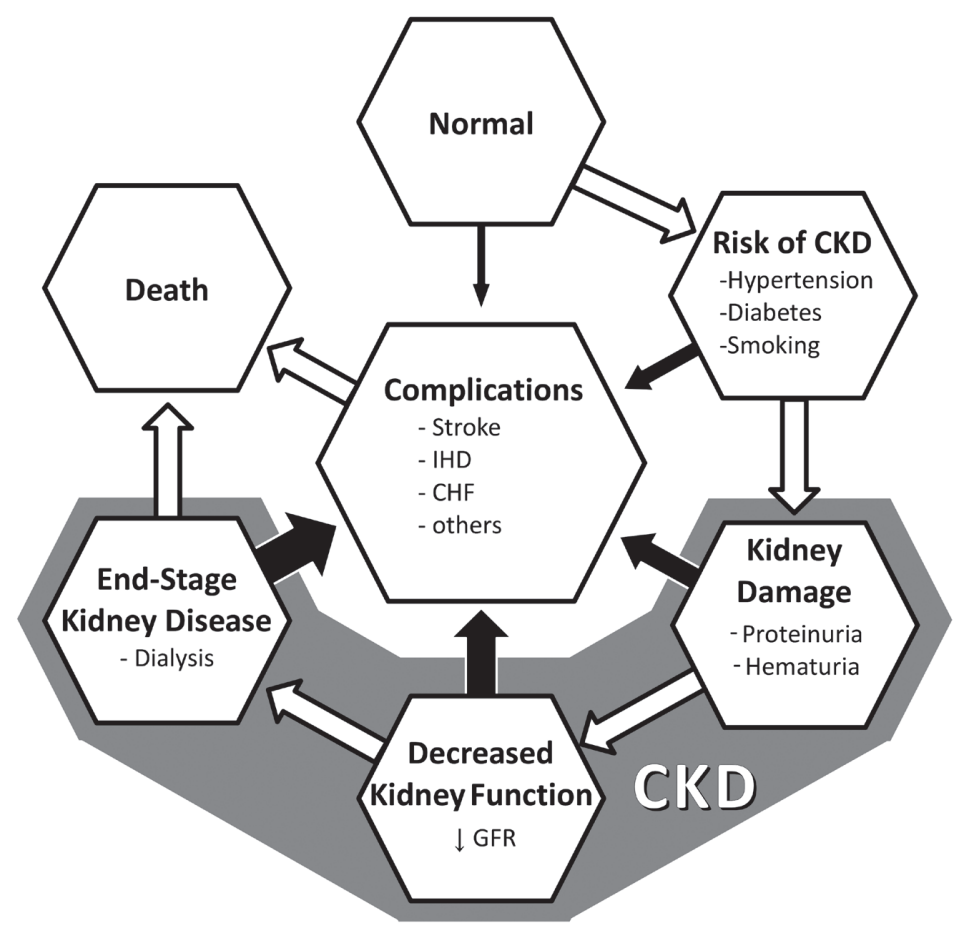

Fig. 1. Conceptual natural history of CKD.

The original figure by the Japanese Society of Nephrology was translated into English.

indicate not only the severity of kidney disease, but also the risk for CVD. This scheme was developed based on previous and recent epidemiological evidence, as reviewed below.

\section{Epidemiology of CKD and CVD in Western Countries}

The presence of proteinuria is associated with an increased risk for CVD, as shown by many studies. In the 5209 men in the Framingham study ${ }^{16)}$, the hazards ratios (HRs) for total mortality and cardiovascular mortality were 2.9 (95\% confidence interval, CI, 2.0-4.2) and 1.7 (95\% CI, 1.0-2.9), respectively. In a cohort of 216 diabetic patients in Denmark ${ }^{17}$ ), those with higher levels of albuminuria had an HR of 2.94 (95\%CI, 1.31-6.64) for mortality as compared to those with lower levels of albuminuria. The risk of death from either CVD or non-CVD linearly increased against log-transformed urinary albumin concentration among 40548 inhabitants of the city of Groningen, the Netherlands ${ }^{4)}$. In the observational cohort of 8206 non-diabetic hypertensive patients with left ventricular hypertrophy who participated in the LIFE study ${ }^{18)}$, the risk for the composite endpoint (death from CVD, nonfatal stroke, and nonfatal myocardial infarction) was increased by $57 \%$ per 10 times increase in the urinary albumin/creatinine ratio. Very low levels of albuminuria $(\geq 4.8 \mu \mathrm{g} / \mathrm{min})$ were associated with an increased risk of developing coronary heart disease (HR, 2.0; 95\% CI, 1.4-3.0) after adjustment for other relevant risk factors in 2762 participants of the Third Copenhagen City Heart Study ${ }^{19)}$.

Reduced GFR is an important predictor of CVD. In the Atherosclerosis Risk in Communities (ARIC) study including 15350 subjects ${ }^{5)}$, reduced GFR was linearly associated with an increased risk for atherosclerotic CVD (ASCVD) outcomes. Each 10 $\mathrm{mL} / \mathrm{min} / 1.73 \mathrm{~m}^{2}$ lower GFR was associated with an adjusted HR of 1.05 (95\%CI, 1.02-1.09), 1.07 (95\%CI, 1.01-1.12), and 1.06 (95\%CI, 0.99-1.13) for ASCVD, de novo ASCVD, and recurrent ASCVD, respectively. In the 5-year follow-up of 27,998 subjects in the US ${ }^{20)}$, the rate of renal replacement therapy (RRT) including dialysis and transplantation was $1.1 \%, 1.3 \%$, and $19.9 \%$, respectively, for CKD stages 2,3 , and 4, respectively. By comparison, the mortality rate in 5 years was $19.5 \%, 24.3 \%$, and $45.7 \%$ for CKD stages 2, 3, and 4, respectively. This study indicates that CKD patients are more likely to die before starting RRT. According to the statistical report ${ }^{21)}$ in 1120295 adults within a large, integrated system of 
health care delivery in the US, the incidence of CVD events showed a stepwise increase as eGFR fell. The adjusted relative risk in the group with eGFR $<15$ $\mathrm{mL} / \mathrm{min} / 1.73 \mathrm{~m}^{2}$ was 3.4 as compared with the group with $\mathrm{eGFR} \geq 60 \mathrm{~mL} / \mathrm{min} / 1.73 \mathrm{~m}^{2}$. Similarly, the risks for hospitalization and death were higher in the lower eGFR categories. In the observational cohort of 4484 apparently healthy subjects in the Rotterdam Study, reduced kidney function as evidenced by either reduced eGFR or calculated creatinine clearance (CCr) was an independent risk factor for myocardial infarction $^{22)}$. Among the 14857 volunteers in the USA (ARIC study), excluding those with congestive heart failure $^{23)}$, the risk of the combination of hospitalization and mortality due to heart failure was higher for those with reduced eGFR $<60 \mathrm{~mL} / \mathrm{min} / 1.73 \mathrm{~m}^{2}$ as compared with those with eGFR $>90 \mathrm{~mL} / \mathrm{min} / 1.73$ $\mathrm{m}^{2}$ (HR 1.94, 95\%CI, 1.49-2.53). Another report of the ARIC study ${ }^{24)}$ showed that the risk of developing symptomatic stroke was independently predicted by CKD as defined by eGFR $<60 \mathrm{~mL} / \mathrm{min} / 1.73 \mathrm{~m}^{2}$ (HR, $1.22 ; 95 \% \mathrm{CI}, 1.02-1.44)$ and by increased systolic blood pressure (HR, 1.18; 95\%CI, 1.14 to 1.21 per $10-\mathrm{mmHg}$ rise). Interestingly, however, individuals with CKD had a J-shaped relationship between stroke outcomes and systolic blood pressure (SBP) such that those with SBP $<120 \mathrm{mmHg}$ have significantly higher risk than individuals with CKD and SBP between 120 and $129 \mathrm{mmHg}$. Such a J shape was not seen in individuals without $\mathrm{CKD}$.

The amount of albuminuria and decreased eGFR synergistically increases the risk for $\mathrm{CVD}^{21)}$. In a cohort of 10640 participants of "The Action in Diabetes and Vascular disease: preterAx and diamicroNMR Controlled Evaluation" (ADVANCE) study, the risk for CVD was evaluated in relation to the baseline urinary albumin-to-creatinine ratio (ACR) and eGFR ${ }^{25)}$. During the average follow-up of 4.3 years, 938 cardiovascular events occurred. The multivariateadjusted HR for CVD events was 2.48 (95\% CI, 1.74-3.52) for every 10-fold increase in baseline ACR, and 2.20 (95\% CI, 1.09-4.43) for every halving of baseline eGFR. There was no significant interaction between the effects of higher ACR and lower eGFR. Patients with both ACR $>300 \mathrm{mg} / \mathrm{g}$ and eGFR $<60$ $\mathrm{mL} / \mathrm{min}$ per $1.73 \mathrm{~m}^{2}$ at baseline had a 3.2-fold higher risk for cardiovascular diseases.

These reports consistently indicate that the risk of CVD is increased in the presence of CKD in Western countries.

\section{Epidemiology of CKD and CVD in the Japanese General Population}

Table 2 summarizes five major epidemiological studies in the Japanese general population reporting an increased risk of CVD in CKD.

In the Hisayama Study ${ }^{26)}$, Ninomiya et al. reported that the cumulative incidence of combined CVD during the 12 years of follow-up was $35.6 \%$ in male subjects with CKD as defined by reduced eGFR $<60 \mathrm{~mL} / \mathrm{min} / 1.73 \mathrm{~m}^{2}$, as compared with $12.0 \%$ in male subjects with eGFR $\geq 60 \mathrm{~mL} / \mathrm{min} / 1.73 \mathrm{~m}^{2}$. In the multivariate adjusted model, the presence of CKD was an independent predictor of the occurrence of ischemic heart disease in men ( $\mathrm{HR}, 2.26$; $95 \% \mathrm{CI}$, 1.06-4.79), and for the occurrence of ischemic stroke in women (HR, 1.91; 95\% CI, 1.15-3.15). CKD was not significantly associated with the risk for hemorrhagic stroke in this cohort.

Kokubo et al. reported the results of the Suita Study ${ }^{27)}$ showing a graded increase in the risk of developing incident CVD (myocardial infarction and stroke) with a lower eGFR at baseline. In men, as compared with subjects with normal eGFR ( $\geq 90 \mathrm{~mL} /$ $\left.\mathrm{min} / 1.73 \mathrm{~m}^{2}\right)$, HRs $(95 \% \mathrm{CI})$ for incident CVD were 1.21 (0.85-1.70), 1.78 (1.08-2.94), 2.38 (1.21-4.68) for those with eGFR of $60-89,50-59$, and $<50 \mathrm{~mL} /$ $\min / 1.73 \mathrm{~m}^{2}$, respectively. Very similar HRs were calculated for women.

In the Japan Arteriosclerosis Longitudinal Study ${ }^{28)}$, Ninomiya et al. calculated the risk of myocardial infarction, stroke, combined CVD, and all-cause mortality associated with reduced GFR in 30657 Japanese individuals 40 to 89 years of age without preexisting CVD or kidney failure. The age- and sex-adjusted hazards ratios for myocardial infarction, stroke, combined CVD, and all-cause death in subjects with GFR $<60 \mathrm{~mL} / \mathrm{min} / 1.73 \mathrm{~m}^{2}$ as compared with those with GFR $\geq 90 \mathrm{~mL} / \mathrm{min} / 1.73 \mathrm{~m}^{2}$ were 3.35 (1.94-5.79), 2.06 (1.51-2.81), 2.26 (1.71-2.99), and 1.70 (1.44$2.00)$, respectively. In models with further adjustment for systolic blood pressure, diabetes mellitus, serum total cholesterol, body mass index, current smoking, the hazards ratios were 2.37 (1.29-4.34), 1.41 (0.99$2.00), 1.57$ (1.14-2.15), and 1.65 (1.38-1.97), respectively. When the same analyses were performed in men and women separately, male subjects with GFR $<60 \mathrm{~mL} / \mathrm{min} / 1.73 \mathrm{~m}^{2}$ showed an increased risk of myocardial infarction with a hazard ratio of 2.56 (1.24-5.27), and female subjects with GFR $<60 \mathrm{~mL} /$ $\mathrm{min} / 1.73 \mathrm{~m}^{2}$ showed an increased risk of stroke with a hazard ratio of $1.98(1.15-3.42)$ in multivariateadjusted models. These results are similar to those 
Table 2. Epidemiological studies reporting the increased risk of CVD in CKD in the Japanese general population

\begin{tabular}{|c|c|c|c|}
\hline Study & $\begin{array}{l}\text { Subject number } \& \\
\text { Follow-up period }\end{array}$ & $\begin{array}{l}\text { Cardiovascular } \\
\text { endpoints }\end{array}$ & Results \\
\hline $\begin{array}{l}\text { Hisayama Study }{ }^{26)} \\
\text { (Ninomiya et al., 2005) }\end{array}$ & $\begin{array}{l}\mathrm{N}=2634 \\
1110 \text { men } \\
1524 \text { women } \\
12 \text { years }\end{array}$ & $\begin{array}{l}\text { Incident CVD } \\
\text { (CHD, ischemic } \\
\text { stroke and } \\
\text { hemorrhagic stroke) }\end{array}$ & $\begin{array}{l}\text { In multivariate adjusted models, CKD was an independent } \\
\text { risk factor of coronary heart disease in men (HR 2.26; } \\
95 \% \text { CI } 1.06-4.79 \text { ), whereas CKD was an independent } \\
\text { risk factor of ischemic stroke in women (HR } 1.91 ; 95 \% \text { CI } \\
1.15-3.15 \text { ). No significant association was found between } \\
\text { CKD and hemorrhagic stroke. }\end{array}$ \\
\hline
\end{tabular}

\begin{tabular}{|c|c|}
\hline $\begin{array}{l}\text { Ibaraki Prefecture Cohort }{ }^{30} \text { ) } \\
\text { (Irie et al., 2006) }\end{array}$ & $\begin{array}{l}\mathrm{N}=91432 \\
\quad 30764 \text { men } \\
\quad 60668 \text { women } \\
10 \text { years }\end{array}$ \\
\hline
\end{tabular}

Proteinuria was an independent risk factor of CVD death in men (HR 1.38; 95\%CI 1.05-1.79) and women (HR 2.15; 95\%CI 1.64-2.81). Reduced eGFR ( $<60$ vs. $\geq 100$ was an independent risk factor of CVD death in men (HR 1.65; 95\%CI 1.25-2.18) and women (HR 1.81; 95\%CI 1.39-2.36). When compared with those without proteinuria and without decreased eGFR $(<60)$, those with both proteinuria and decreased eGFR had increased risk of CVD death in men (HR 2.15; 95\%CI 1.28-3.60) and in women (HR 4.00; 95\%CI 2.62-6.10).

\begin{tabular}{|c|c|c|}
\hline $\begin{array}{l}\text { NIPPON DATA90 }{ }^{29)} \\
\text { (Nakamura et al., 2006) }\end{array}$ & $\begin{array}{l}N=7316 \\
3047 \text { men } \\
4269 \text { women } \\
10 \text { years }\end{array}$ & CVD death \\
\hline
\end{tabular}

In multivariate adjusted models, eGFR $<60$ was associated with increased risk of CVD death (HR 1.20; 95\%CI 0.82-1.76). As compared with eGFR $>90$, HRs were 1.15 (95\%CI 0.67-1.99) for those with eGFR between 45 and 60, 1.23 (95\%CI 0.49-3.09) for those with eGFR between 30 and 45, 5.52 (95\%CI 1.62-18.75) for those with eGFR between 15 and 30, and 9.12 (95\%CI 2.12 39.29) for those with eGFR $<15$.

\begin{tabular}{|c|c|c|c|}
\hline $\begin{array}{l}\text { JALS-ECC }{ }^{28)} \\
\text { (Ninomiya, et al., 2008) }\end{array}$ & $\begin{array}{l}\mathrm{N}=23031 \\
9574 \text { men } \\
13459 \text { women } \\
7.4 \text { years }\end{array}$ & Incident CVD & $\begin{array}{l}\text { As compared with those with GFR } \geq 90 \text {, subjects with } \\
\text { GFR }<60 \text { had an increased risk for stroke, MI, combined } \\
\text { CVD, and all-cause mortality. In multivariate adjusted } \\
\text { models, reduced GFR was an independent risk factor for } \\
\text { MI in men (HR 2.56; 95\%CI 1.24-5.27), whereas for } \\
\text { stroke in women (HR1.98; 95\%CI 1.15-3.42). }\end{array}$ \\
\hline $\begin{array}{l}\text { Suita Study }{ }^{27} \text { ) } \\
\text { (Kokubo et al., 2009) }\end{array}$ & $\begin{array}{l}\mathrm{N}=5494 \\
2570 \text { men } \\
2924 \text { women } \\
11.7 \text { years }\end{array}$ & $\begin{array}{l}\text { Incident CVD } \\
\text { (MI, stroke) }\end{array}$ & $\begin{array}{l}\text { In men, as compared with subjects with normal eGFR } \\
(\geq 90) \text {, HRs }(95 \% \mathrm{CI}) \text { for incident CVD were } 1.21(0.85- \\
1.70) \text { for those with eGFR between } 60 \text { and } 89,1.78 \\
(1.08-2.94) \text { for those with eGFR between } 50 \text { and } 59 \text {, and } \\
2.38(1.21-4.68) \text { for those with eGFR } \leq 50 \text {. In women, } \\
\text { HRs }(95 \% \text { CI) for incident CVD were } 1.21(0.80-1.84) \text {, } \\
1.76(1.05-2.93) \text {, and } 2.31(1.20-4.43) \text { for those with } \\
\text { eGFR of } 60-89,50-59 \text {, and }<50 \text {, respectively. }\end{array}$ \\
\hline
\end{tabular}

The unit for eGFR is $\mathrm{mL} / \mathrm{min} / 1.73 \mathrm{~m}^{2}$.

Abbreviations: CKD, chronic kidney disease; CVD, cardiovascular disease; MI, myocardial infarction; HR, hazards ratio; CI, confidence interval; eGFR, estimated glomerular filtration rate.

from the Hisayama Study, showing that CKD increases the risk of myocardial infarction in men, whereas it increases the risk of stroke (ischemic stroke) in women.

Nakamura et al. reported the association between CKD and death from CVD among 7316 participants of NIPPON DATA90 ${ }^{29)}$. After adjusting for major risk factors, as compared with normal eGFR $(>90$
$\mathrm{mL} / \mathrm{min} / 1.73 \mathrm{~m}^{2}$ ), a lower eGFR was associated with worse outcome. HRs (95\%CI) were 1.15 (0.67-1.99), 1.23 (0.49-3.09), $5.52(1.62-18.75)$, and 9.12 (CI 2.12-39.29), for those with eGFR of 45-60, 30-45, $15-30$, and $<15 \mathrm{~mL} / \mathrm{min} / 1.73 \mathrm{~m}^{2}$, respectively.

In the Ibaraki Prefecture Cohort, Irie et al. ${ }^{30}$ showed the synergistic effects of reduced eGFR and proteinuria on the risk for CVD. In a 10-year pro- 


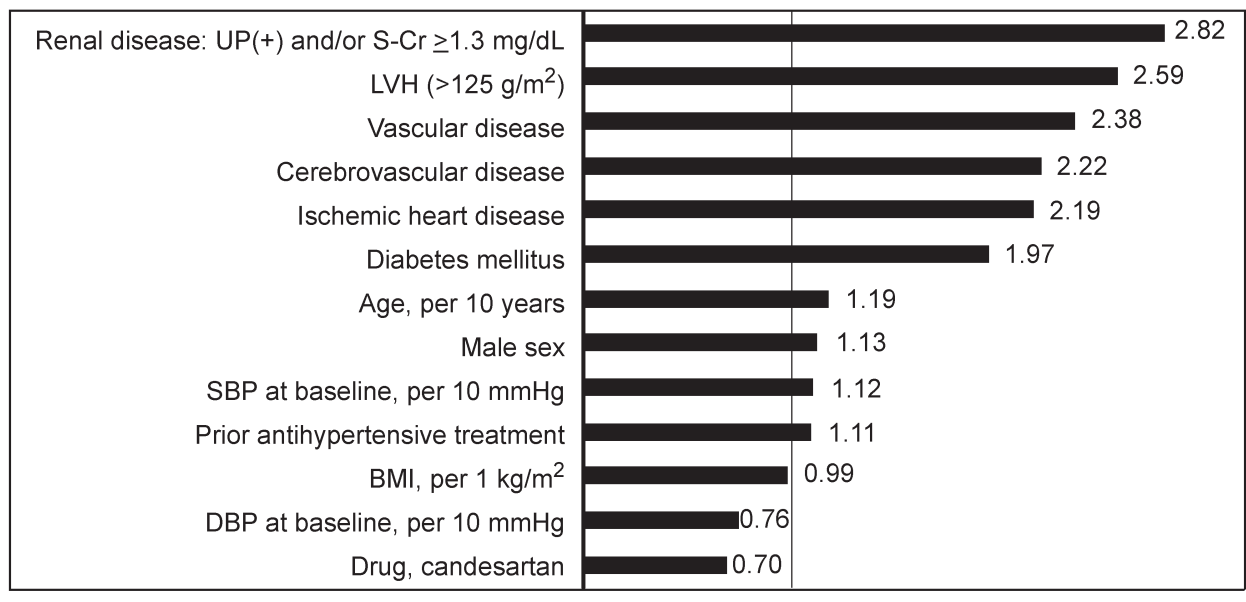

Variables

Hazards Ratios

Fig. 2. Comparison of hazards ratios of CKD and other risk factors for CVD in the cohort of CASE-J.

Hazards ratio for each variable is adjusted for the other variables in the figure. This figure was developed by the authors based on the original paper by Yasuno et al. ${ }^{34)}$

spective cohort study of 30764 men and 60668 women aged 40-79 years, both the presence of proteinuria and the reduction of eGFR $<60 \mathrm{~mL} /$ $\min / 1.73 \mathrm{~m}^{2}$ were predictors of cardiovascular or allcause death. The risk of CVD death was two-fold higher in men and 4-6-fold higher in women in those with both proteinuria and reduced eGFR as compared with those without proteinuria and reduced eGFR.

Other observational studies from Japan ${ }^{31,32)}$ also provide additional evidence that $\mathrm{CKD}$ is a high-risk condition for CVD.

\section{Meta-Analysis of Studies in the General Populations Worldwide}

Chronic Kidney Disease Progression Consortium performed a collaborative meta-analysis of 21 general population cohorts from Western and Asian countries including Japan, Korea, Taiwan, and China ${ }^{33)}$. In studies with ACR including 105872 participants (730577 person-years), reduced eGFR was associated with an increased risk of all-cause and cardiovascular mortality. ACR was also associated with an increased risk of all-cause and cardiovascular mortality. eGFR and ACR were multiplicatively associated with a risk of mortality without evidence of interaction. Similar findings were recorded in studies with urinary protein dipstick measurements including 1128310 participants (4732110 person-years). This large-scale metaanalysis has established that reduced eGFR and increased ACR independently and synergistically increase the risk of worse outcomes.

\section{Impact of CKD on CVD as Compared with that of Other Risk Factors}

Yasuno et al. ${ }^{34)}$ performed a post-hoc analysis of data of 1447 hypertensive patients who participated in the Candesartan Antihypertensive Survival Evaluation in Japan trial (CASE-J). They compared the HRs for CVD between CKD and other established risk factors (Fig. 2). CVD was defined as composite cardiovascular events including sudden death, cerebrovascular events, cardiac events, vascular events including dissecting aortic aneurysm and peripheral arterial disease, and renal events (serum creatinine $\geq 4.0 \mathrm{mg} / \mathrm{dL}$, doubling of serum creatinine, or end-stage renal disease). During the mean follow-up period of 3.3 years, 87 composite CVD events were reported, including 10 renal events. In a multiple Cox regression model, CVD events showed the strongest association with renal dysfunction as defined by proteinuria and/or serum creatinine $\geq 1.3 \mathrm{mg} / \mathrm{dL}$ with $\mathrm{HR}(95 \% \mathrm{CI})$ of 2.82 (1.18-4.39). This figure was higher than the HRs of left ventricular hypertrophy $\geq 125 \mathrm{~g} / \mathrm{m}^{2}$ (HR 2.59; 95\%CI 1.55-4.34), pre-existing ischemic heart disease (HR 2.19; 95\%CI 1.39-3.44), and diabetes mellitus (HR 1.97; 95\%CI 1.26-3.06). This result clearly indicates that $\mathrm{CKD}$ is a very strong predictor of CVD in this Japanese hypertensive population treated with antihypertensive medication.

\section{Epidemiology in CKD stage 5D}

According to the report from USA in $1998^{2)}$, the 
Table 3. Relative risk of death from cardiovascular disease in patients with CKD stage $5 \mathrm{D}$ as compared with the general population in Japan

\begin{tabular}{|c|c|c|c|c|c|c|c|c|}
\hline $\begin{array}{l}\text { Cause of } \\
\text { death }\end{array}$ & $\begin{array}{l}\text { Age } \\
\text { (years) }\end{array}$ & \multicolumn{3}{|c|}{ Japanese general population (2005) } & \multicolumn{3}{|c|}{ Japanese dialysis patients (2005) } & RR \\
\hline \multirow[t]{4}{*}{ IHD } & $30-44$ & 26153858 & 1139 & 4 & 16153 & 12 & 74 & 17.1 \\
\hline & $45-59$ & 26617876 & 6275 & 24 & 67623 & 145 & 214 & 9.1 \\
\hline & $60-74$ & 22584589 & 19137 & 85 & 102880 & 521 & 506 & 6.0 \\
\hline & $75-89$ & 10518734 & 37760 & 359 & 49515 & 409 & 826 & 2.3 \\
\hline \multirow{3}{*}{$\mathrm{CHF}$} & $45-59$ & 26617876 & 2354 & 9 & 67623 & 525 & 776 & 87.8 \\
\hline & $60-74$ & 26360000 & 7810 & 30 & 102880 & 2173 & 2112 & 71.3 \\
\hline & $75-89$ & 10518734 & 27354 & 260 & 49515 & 2580 & 5211 & 20.0 \\
\hline \multirow[t]{2}{*}{ Stroke } & $30-44$ & 26153858 & 1571 & 6 & 16153 & 53 & 328 & 54.6 \\
\hline & $45-59$ & 26617876 & 8553 & 32 & 67623 & 400 & 592 & 18.4 \\
\hline
\end{tabular}

Mortality rate is per 100000 person-years.

Data are derived from statistics by Japanese Society for Dialysis Therapy ${ }^{36}$, Statistical Bureau, Ministry of Internal Affairs and Communications, and Ministry of Health, Labour and Welfare, Japan ${ }^{37)}$.

Relative risk of dialysis as compared with the general population was calculated by the authors.

Abbreviations: IHD, ischemic heart disease; CHF, congestive heart failure; RR, relative risk.

relative risk for CVD death in middle-aged hemodialysis patients was in the range of 10 to 30 as compared with the general population, and a much higher relative risk was shown for younger patients.

In Japan, the relative risk of death from ischemic heart disease was 9.3 to 23.3 times higher for dialysis patients than the general population aged between 30 and 74 years in $1993^{35}$. We re-calculated the relative risk of death from CVD in Japanese patients with CKD stage $5 \mathrm{D}$ as compared with the Japanese general population based on the more recent report by JSDT $^{36)}$ and the national statistics ${ }^{37)}$ in 2005 (Table 3). Dialysis patients showed 6.0 to 17.1 times higher risk of death from ischemic heart disease than the general population in the same age categories. Although these figures are somewhat lower than previously, it is important to note that the relative risk of ischemic heart disease for $\mathrm{CKD}$ stage $5 \mathrm{D}$ is much higher than for early stages of CKD. Furthermore, in CKD stage $5 \mathrm{D}$, the relative risks of death from stroke and congestive heart failure are much higher than from ischemic heart disease.

\section{Dyslipidemia in CKD}

$\mathrm{CKD}$ is an important condition that results in secondary dyslipidemia. Since CKD is defined by the presence of proteinuria and/or reduced GFR, dyslipid- emia secondary to CKD can be discussed separately in proteinuria-dominant CKD and reduced GFR-dominant CKD (Table 4).

Nephrotic syndrome is a representative condition for the first group of patients ${ }^{38)}$. The hepatic production of very low density lipoprotein (VLDL) is elevated because of a nonspecific increase in protein secretion by the liver to compensate for hypoalbuminemia caused by massive loss of serum proteins into urine. VLDL is metabolized into low density lipoprotein (LDL) by the action of lipoprotein lipase (LPL) in peripheral tissues. Urinary loss of apoC-II, an activator of LPL, could decrease LPL action, resulting in impaired catabolism of TG-rich lipoproteins into LDL. Thus, the lipoprotein phenotypes in this condition vary among type $\Pi$ a (increased LDL), type $\Pi b$ (increased LDL and VLDL), and type IV (increased VLDL), depending on the degree of LPL suppression. HDL-C is reported to be unchanged or reduced in human nephrotic syndrome ${ }^{38)}$. Reduction of plasma HDL-C may be explained to some extent by the loss of $\alpha$-migrating lipoproteins into urine ${ }^{39)}$.

The second group of patients have chronic renal failure $^{40)}$. Hepatic VLDL production is not increased in renal failure, whereas the degradation of TG-rich lipoproteins is impaired ${ }^{41)}$. Post-heparin plasma LPL activity is reported to be normal or decreased, whereas post-heparin plasma LPL protein mass is not 
Table 4. Dyslipidemias in CKD

\begin{tabular}{lll}
\hline $\begin{array}{c}\text { Changes in lipoprotein } \\
\text { metabolism }\end{array}$ & \multicolumn{1}{c}{$\begin{array}{c}\text { Proteinuria-dominant CKD } \\
\text { (Nephrotic syndrome) }\end{array}$} & \multicolumn{1}{c}{$\begin{array}{c}\text { Reduced GFR-dominant CKD } \\
\text { (renal failure) }\end{array}$} \\
\hline $\begin{array}{l}\text { Predominant lipoprotein } \\
\text { phenotypes }\end{array}$ & $\begin{array}{l}\text { Type IIa, IIb, IV } \\
\text { (increased LDL, with/without } \\
\text { increased VLDL) }\end{array}$ & $\begin{array}{l}\text { Type IV, III } \\
\text { (increased VLDL, increased IDL, decreased LDL), } \\
\text { decreased HDL-C }\end{array}$ \\
\hline Hepatic VLDL production & Increased & Normal \\
\hline $\begin{array}{l}\text { Catabolism of TG-rich } \\
\text { lipoproteins }\end{array}$ & $\begin{array}{l}\text { Impaired in some cases due to } \\
\text { urinary losses of apoC-II }\end{array}$ & $\begin{array}{l}\text { Impaired LPL function due to increased apoC-III. } \\
\text { Decreased HTGL level }\end{array}$ \\
\hline Clearance of LDL & Impaired & Impaired \\
\hline Chylomicron metabolism & Impaired & Impaired \\
\hline Reverse cholesterol transport & LCAT, CETP & $\begin{array}{l}\text { LCAT, CETP } \\
\text { Accumulated pre-beta HDL }\end{array}$ \\
\hline Lipoprotein modifications & & Carbamylation, Glycosylation, Oxidation \\
\hline
\end{tabular}

decreased ${ }^{42)}$. Patients with renal failure have an increased serum concentration of apoC-III ${ }^{43)}$, an inhibitor of LPL, as well as increased apoC-III/C-II ratio. Also, patients with renal failure show marked reduction of hepatic triglyceride lipase (HTGL) activity and HTGL protein mass in post-heparin plasma ${ }^{42)}$. Decreased HTGL explains the accumulation of IDL ${ }^{44)}$ and normal LDL size ${ }^{45)}$ in renal failure. The most typical lipoprotein phenotype in renal failure is type IV with decreased high density lipoprotein cholesterol $(\text { HDL-C })^{43}$. In addition, a previous study using agarose gel electrophoresis ${ }^{43}$ reported that as much as $23 \%$ of hemodialysis patients showed a broad $\beta$ pattern or the presence of a mid-band between the $\beta$ and pre- $\beta$ peaks, indicating a high prevalence of remnant accumulation and type III-like phenotype in this population. Possible mechanisms for decreased HDL-C are low activity of lecithin:cholesterol acyltransferase (LCAT), and enhanced lipid transfer between HDL and accumulated VLDL particles.

Dislipidemia is worsened when both CKD and diabetes mellitus are present at the same time. Among diabetic patients, the presence of nephropathy is associated with increased VLDL and IDL, as well as decreased HDL ${ }^{46)}$. Similar impacts of diabetes and CKD have been found in a comparison of hemodialysis patients with and without diabetes mellitus ${ }^{477}$.

\section{Atherosclerotic Arterial Changes in CKD and Role of Dyslipidemia}

Two studies from Japan ${ }^{48,49)}$ show that more than $50 \%$ of CKD patients starting dialysis treatment had a significant extent of coronary artery stenosis evidenced by angiography. Interestingly, when the incident dialysis patients were followed-up for 2 years, only $4 \%$ of patients experienced major cardiac events (MACE) among those without coronary artery disease at the start of dialysis. In contrast, about $50 \%$ patients experienced MACE within 6 months among those who had coronary artery disease at the initiation of dialysis ${ }^{50)}$. These studies indicate that the development of clinical ischemic heart disease after starting dialysis is due mostly to advanced coronary atherosclerosis that developed before starting dialysis.

Angiographic studies are difficult to perform in pre-dialysis patients with $\mathrm{CKD}$; however, atherosclerotic changes can be evaluated by measuring arterial wall thickness using ultrasound, and by measuring arterial stiffness using a pulse wave analyzer. Carotid arterial intima-media thickness (IMT) was significantly increased in patients under maintenance hemodialysis therapy ${ }^{51)}$, but this was not fully explained by dialysis treatment, because a comparable increase in IMT was present in pre-dialysis patients with $\mathrm{CKD}^{52}$. Also, IMT was not correlated with the duration of hemodialysis. Aortic pulse wave velocity (PWV) was increased in maintenance hemodialysis patients ${ }^{53)}$, But this was also not fully explained by dialysis treatment, because there was a comparable increase in aortic PWV in pre-dialysis patients with $\mathrm{CKD}^{54)}$. Aortic PWV was not correlated with the duration of hemodialysis. In a recent report from Italy ${ }^{55)}$, the annual increase of the cross-sectional area of carotid atherosclerotic plaque was higher in $\mathrm{CKD}$ patients with $\mathrm{CCr}$ of $29-50 \mathrm{~mL} / \mathrm{min}$ than in those with $\mathrm{CCr}$ of 20-29 
$\mathrm{mL} / \mathrm{min}$, suggesting more rapid plaque growth in CKD stage 3 and slowed progression in later stages. These data are in agreement with the above studies using coronary angiography ${ }^{48,49)}$, indicating that atherosclerotic changes are advanced in the pre-dialysis period of CKD.

Regarding the role of dyslipidemia in advanced atherosclerosis in patients with CKD, both carotid IMT $^{52,56)}$ and aortic PWV ${ }^{53,54,57)}$ are reported to be positively associated with non-high-density lipoprotein cholesterol (non-HDL-C), independent of other risk factors in subjects with various degrees of CKD. Among non-HDL lipoproteins, IDL showed the closest association with aortic PWV in hemodialysis patients ${ }^{53)}$. These studies support the notion that dyslipidemia plays an important role in promoting atherosclerosis in CKD.

\section{Reverse Epidemiology between Cholesterol and Death from CVD}

A lower level of serum total cholesterol is known to predict a higher risk of all-cause mortality in hemodialysis cohorts ${ }^{58)}$. This is also true when death from CVD was taken as an endpoint ${ }^{59)}$. Since hypercholesterolemia is an established risk factor for CVD in the general population, this strange relationship between death risk and the risk factor of CVD is called 'reverse causality', 'reverse epidemiology' ${ }^{60)}$, or 'cholesterol paradox' ${ }^{61)}$. Importantly, in these studies reporting a paradoxical association, the endpoints are not incident CVD, but death from CVD or death from all-cause. In addition, no adjustment is performed for possible confounders such as advanced age, nutritional status, and inflammation. Since death from CVD occurred only when a subject experienced incident CVD and then died, the risk factors of CVD death may be different from those of incident $\mathrm{CVD}^{61,62)}$.

\section{Non-HDL-C as an Independent Predictor of Incident Atherosclerotic CVD in CKD}

A recent observational cohort study by JSDT ${ }^{63)}$ examined the relationship between serum lipids and incident CVD among 45390 hemodialysis patients. After adjustment for age, sex, diabetes mellitus, dialysis vintage, body mass index, serum albumin and C-reactive protein (CRP) levels, the risk of incident myocardial infarction was positively associated with non-HDL-C and inversely with HDL-C. This result is similar to the epidemiology in the general population. Interestingly, among those who experienced new CVD including myocardial infarction, cerebral infarc- tion, and cerebral hemorrhage, the risk of death after CVD was independently predicted by higher age, higher CRP, and lower body mass index. Since total cholesterol was inversely correlated with CRP, and positively with serum albumin and body mass index in these patients, these results strongly suggest that the reverse epidemiology of cholesterol is confounded by the effects of malnutrition (protein-energy wasting) and inflammation on the risk of fatality after incident CVD.

\section{Traditional and Non-Traditional Risk Factors for CVD in CKD}

The risk of CVD death is elevated in those with CKD, particularly in those with CKD stage $5 \mathrm{D}$. Sarnak et al. ${ }^{6}$ listed the candidates of traditional and non-traditional risk factors that may explain the increased risk of CVD in CKD. Traditional risk factors are older age, male sex, hypertension, higher LDL-C, lower HDL-C, diabetes mellitus, smoking, physical inactivity, menopause, family history of CVD, and left ventricular hypertrophy. They also proposed nontraditional risk factors such as albuminuria, homocysteine, lipoprotein(a), apolipoprotein(a) isoforms, lipoprotein remnants, anemia, abnormal calcium/phosphate metabolism, extracellular fluid overload, electrolyte imbalance, oxidative stress, inflammation (elevated CRP), malnutrition, thrombogenic factors, sleep disturbances, and altered nitric oxide/endothelin balance.

Some experts have proposed the hypothesis that malnutrition and inflammation promote atherosclerosis (MIA syndrome) ${ }^{64)}$ in dialysis patients; however, the markers of malnutrition were not associated with the risk of incident CVD, but with the increased risk of fatality after incident CVD as shown in the study by JSDT ${ }^{63)}$. We speculate that some listed non-traditional risk factors may be factors associated with increased fatality.

\section{Lipid-Lowering Treatment and Risk for CVD in Early Stages of CKD}

There are several post-hoc analyses of large randomized controlled trials (RCTs) that calculated the risk reduction with statin in subjects with CKD (Table 5). In such subanalyses of the Heart Protection Study $(\mathrm{HPS})^{65)}$, ASCOT-LLA ${ }^{66)}$ and Pravastatin Pooling Project $(\mathrm{PPP})^{67)}$, using simvastatin, atorvastatin and pravastatin, respectively, the risk of CVD was significantly reduced. Very interestingly, the relative risk reduction was greater in the subgroup with $\mathrm{CKD}$ than 
Table 5. Effects of lipid-lowering medications on CVD risk in patients with early stages of CKD

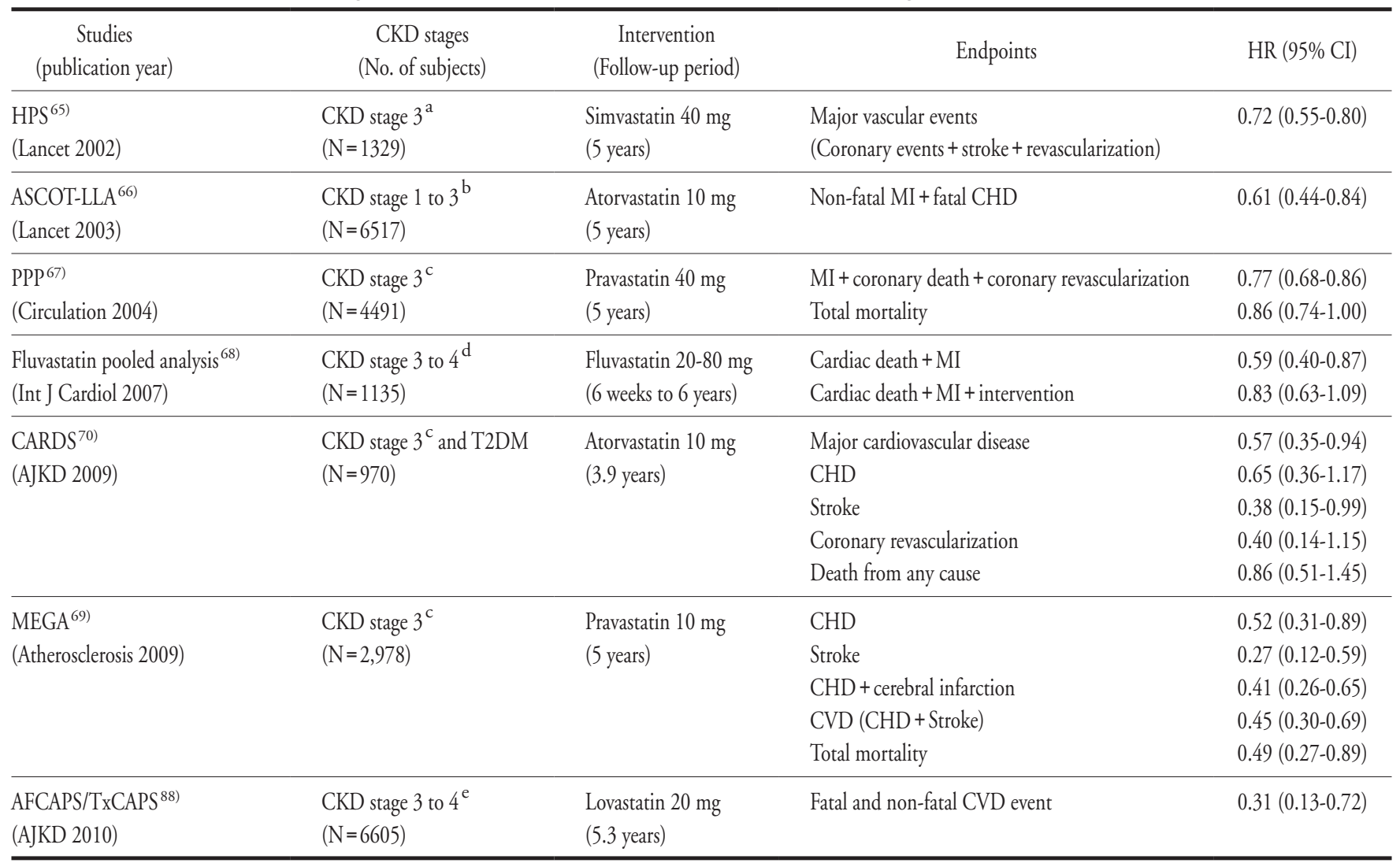

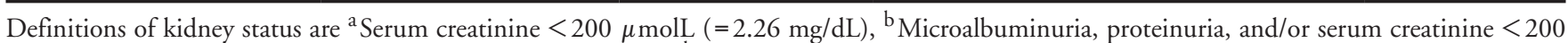
$\mu$ molL $\left(=2.26 \mathrm{mg} / \mathrm{dL}\right.$ ), ${ }^{\mathrm{c}}$ eGFR of $30-59.99 \mathrm{~mL} / \mathrm{min} / 1.73 \mathrm{~m}^{2},{ }^{\mathrm{d}} \mathrm{CCr}<50 \mathrm{~mL} / \mathrm{min}$, and ${ }^{\mathrm{e}} \mathrm{eGFR}$ of $15-60 \mathrm{~mL} / \mathrm{min} / 1.73 \mathrm{~m}{ }^{2}$.

Abbreviations: HR, hazards ratio; CI, confidence interval; MI, myocardial infarction; CHD, coronary heart disease; CVD, cardiovascular disease; CKD, chronic kidney disease; HPS, Heart Protection Study; ASCOT-LLA, Anglo-Scandinavian Cardiac Outcomes Trial-Lipid Lowering Arm; PPP, Pravastatin Pooling Project; CARDS, Collaborative Atorvastatin Diabetes Study; MEGA, Management of Elevated Cholesterol in the Primary Prevention Group of Adult Japanese; AFCAPS/TxCAPS, Air Force/Texas Coronary Atherosclerosis Prevention Study.

in overall study subjects. In a meta-analysis ${ }^{68)}$, treatment with fluvastatin significantly reduced the risk for combined cardiac death and myocardial infarction by $41 \%$ as compared with a placebo in the subgroup with creatinine clearance $(\mathrm{CCr})<50 \mathrm{~mL} / \mathrm{min}$, the relative risk reduction being greater than $30 \%$ in the subgroup with $\mathrm{CCr} \geq 50 \mathrm{~mL} / \mathrm{min}$. Furthermore, the sub-analysis of MEGA in Japan ${ }^{69)}$, pravastatin treatment reduced the risk for coronary heart disease, stroke, combined CVD events, and total mortality by 48\%, 73\%, 54\% and $52 \%$, respectively as compared with diet therapy alone. The relative risk reductions in CKD patients were much better than in total subjects. A recent subanalysis of $\mathrm{CARDS}^{70)}$, atrovastatin reduced the risk for MACE by $42 \%$ including a $61 \%$ reduction in stroke in type 2 diabetic patients with CKD stage 3. Although CKD was not the primary target population in the above studies, these post-hoc analyses strongly suggest that $\mathrm{CKD}$ is a subpopulation that may have greater benefit with lipid-lowering treatment with statins than those with normal kidney function.

\section{Lipid-Lowering Treatment and Risk for CVD in CKD Stage 5D}

There are only three RCTs with statins in CKD as the primary target population. The first is die Deutsche Diabetes Dialyse Studie (4D, the German Diabetes Dialysis Study) that enrolled 1255 patients with type 2 diabetes mellitus treated with hemodialysis $^{71)}$. The study examined the effect of $20 \mathrm{mg}$ per day of atorvastatin versus a placebo on the composite endpoint of CVD death, nonfatal myocardial infarction and nonfatal stroke for the mean follow-up period of 4 years. Although LDL-C was reduced by $40 \%$, the $8 \%$ reduction in the primary composite endpoint in the atorvastatin arm was not statistically significant. The mean baseline LDL-C was $126 \mathrm{mg} / \mathrm{dL}$. 
Table 6. Effects of lipid-lowering medications on CVD risk in patients with advanced stages of CKD

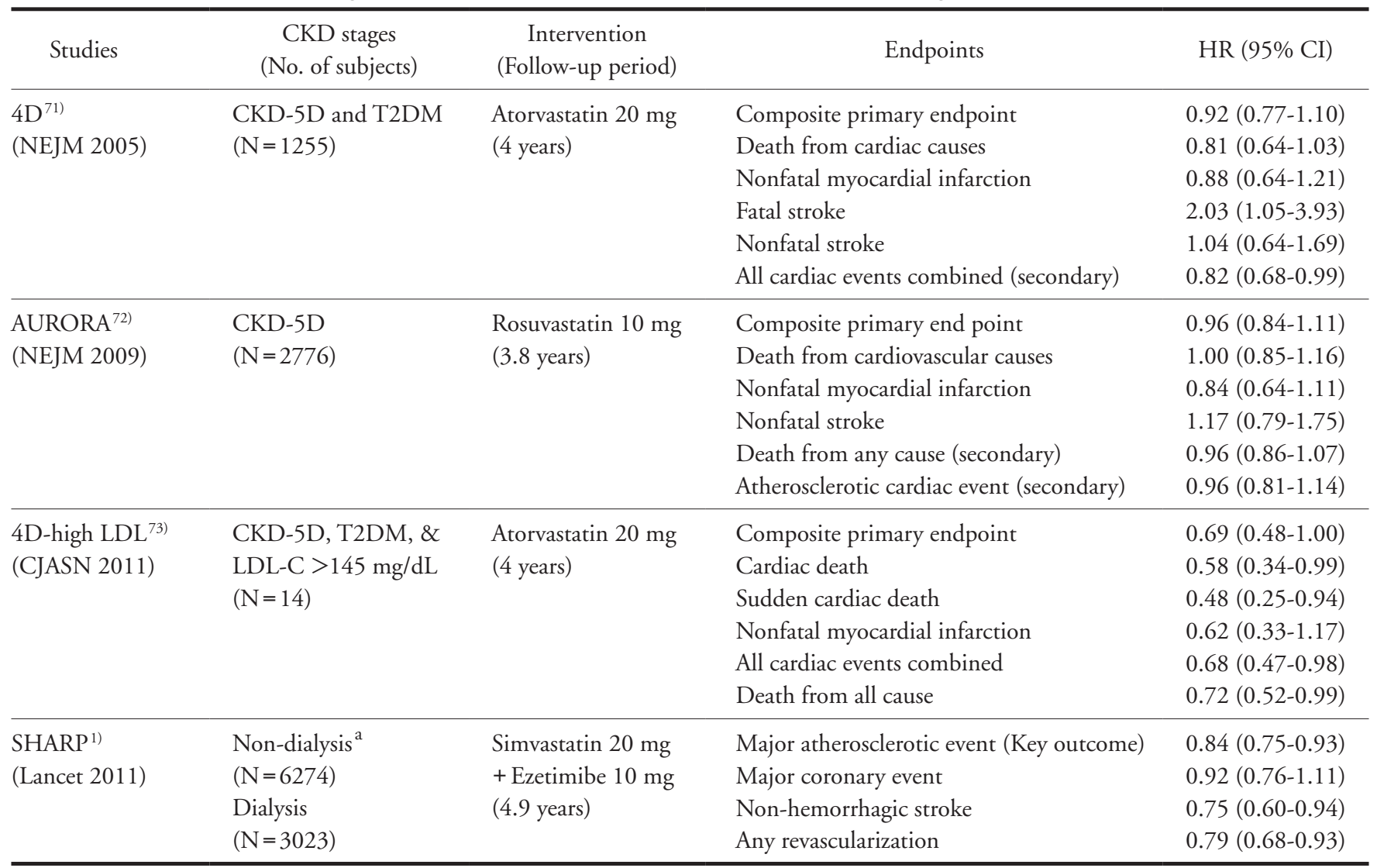

${ }^{a}$ Definition of kidney status: serum creatinine $>1.7 \mathrm{mg} / \mathrm{dL}$ for men and $>1.5 \mathrm{mg} / \mathrm{dL}$ for women.

Abbreviations: HR, hazards ratio; CI, confidence interval; 4D, Die Deutsche Diabetes Dialyse; AURORA, A Study to Evaluate the Use of Rosuvastatin in Subjects on Regular Hemodialysis: An Assessment of Survival and Cardiovascular Events; SHARP, Study of Heart and Renal Protection.

The second study is AURORA ${ }^{72)}$, which enrolled 2776 patients treated with dialysis including both diabetic and nondiabetic patients. The intervention was $10 \mathrm{mg}$ per day of rosuvastatin versus a placebo control. The subjects were followed-up for a median of 3.8 years. Although both LDL-C and C-reactive protein levels were decreased in the rosuvastatin group, the $4 \%$ reduction in the composite primary endpoint in the rosuvastatin arm was not statistically significant. The mean baseline LDL-C was $99 \mathrm{mg} / \mathrm{dL}$.

These 'negative' results of $4 \mathrm{D}$ and AURORA may be disappointing, but these results may indicate that the initiation of statin treatment is not effective in reducing CVD risk in patients with a very advanced stage of CKD having low to normal levels of baseline LDL-C. In a recent post-hoc analysis of $4 \mathrm{D}^{73)}$, März et al. found that atorvastatin treatment significantly reduced CVD risk in subjects in the highest quartile of baseline LDL-C $(>145 \mathrm{mg} / \mathrm{dL})$. The HRs $(95 \%$ CI) were $0.69(0.48-1.00)$ for the composite primary endpoint, 0.58 (0.34-0.99) for cardiac death, 0.48 (0.25-0.94) for sudden cardiac death, $0.62(0.33-1.17)$ for nonfatal myocardial infarction, 0.68 (0.47-0.98) for all cardiac events combined, and $0.72(0.52-0.99)$ for death from all causes, respectively. Numbers needed to treat for 5 years were in the range of 3-10 in this subgroup of participants. Thus, it may be that lipid-lowering with statins is very efficacious in patients with CKD stage 5D in reducing CVD risk, but the benefit is limited to those with elevated levels of atherogenic lipoproteins.

The third RCT in CKD is SHARP ${ }^{1)}$. SHARP enrolled 6274 patients not on dialysis and 3023 patients on dialysis. The patients not on dialysis met the inclusion criteria of serum creatinine levels $\geq 1.7$ $\mathrm{mg} / \mathrm{dL}$ in men and $\geq 1.5 \mathrm{mg} / \mathrm{dL}$ in women and the mean eGFR was $23 \mathrm{~mL} / \mathrm{min} / 1.73 \mathrm{~m}^{2}$ at baseline, corresponding to $\mathrm{CKD}$ stage 4 . The intervention was simvastatin $20 \mathrm{mg}$ per day plus ezetimibe $10 \mathrm{mg}$ per day versus a placebo control. The mean follow-up 
period was 4.9 years. The key outcome was a composite of major atherosclerotic events (coronary death, myocardial infarction, non-hemorrhagic stroke, or any revascularization). The simvastatin plus ezetimibe group showed a significantly lower risk of the major atherosclerotic events with $\mathrm{HR}(95 \% \mathrm{CI})$ of 0.83 (0.74-0.94). When the subjects were divided into dialysis and non-dialysis subgroups, the risk reduction rate was 20\% in non-dialysis patients and $9 \%$ in dialysis patients, although no significant heterogeneity was noticed between non-dialysis and dialysis patients $(p=0.25)$.

\section{Possible Reno-Protective Effects of Lipid-Lowering Treatment}

Lipid-lowering treatments may decrease proteinuria and increase or maintain renal function ( $\mathrm{CCr}$ and eGFR). Observational cohort studies ${ }^{75}$ showed that dyslipidemia is an independent predictor of the decline of renal function. Lipid-lowering with statins was reported to decrease albuminuria and proteinuria in observational ${ }^{76)}$ and controlled trials ${ }^{77)}$. A metaanalysis ${ }^{78)}$ showed that statin treatment is associated with decreased ACR as compared with a placebo. LDL apheresis with LDL adsorption columns was also reported to decrease proteinuria and urinary losses of glomerular epithelial cells (podocytes) ${ }^{79)}$.

Statin treatment is associated with increased eGFR or CCr as compared with a placebo in pot-hoc analyses of primary ${ }^{69,70)}$ and secondary prevention trials with statin ${ }^{80,81)}$. Studies performed in Japan also provided similar results. A higher dose of statin was associated with a more impressive increase of eGFR in a post-hoc analysis of the Treating To New target trial $^{81)}$. Some studies indicate that the increase in eGFR was greater in subjects with lower eGFR at baseline. A meta-analysis ${ }^{78}$ ) supports the notion that statins protect against the decline of renal function. Increased eGFR was also reported for Japanese patients with hypercholesterolemia ${ }^{69,82}$.

Endo et al. ${ }^{83)}$ reported that treatment with probucol, a lipid-lowering agent with potent anti-oxidative property, delayed the progression of diabetic nephropathy in their study including 102 patients with overt albuminuria of ACR $>300 \mathrm{mg} / \mathrm{gCr}$ who were followed-up for of 3 years or longer. The probucol group showed a smaller increase in proteinuria and longer time to dialysis initiation, suggesting reno-protective effects of purobucol.

Fibrates may have beneficial effects on the kidneys. According to the FIELD study ${ }^{84)}$, treatment with fenofibrate (200 mg daily) in patients with type
2 diabetes mellitus did not significantly reduce the risk of the primary endpoint (coronary heart disease death or non-fatal myocardial infarction), whereas the treatment was associated with less progression of albuminuria.

\section{Clinical Practice Guidelines for Lipid Management in CKD (Table 7)}

In 2001, the National Cholesterol Education Program (NCEP) Adult Treatment Panel (ATP) III published guidelines that recommend decreasing LDL-C below $100 \mathrm{mg} / \mathrm{dL}$ in adults with ischemic heart disease and those with equivalent risk ${ }^{85)}$. Following the NCEP ATP III guidelines, European Renal Association-European Dialysis Transplantation (ERAEDTA) published guidelines on the management of dyslipidemia in patients with $\mathrm{CKD}^{7)}$ in 2002. In the following year, the National Kidney Foundation Kidney Disease Outcome Quality Initiative (NKF K/ DOQI) released guidelines for dyslipidemia in $\mathrm{CKD}^{8)}$. These guidelines specific for patients with CKD recommend controlling LDL-C below $100 \mathrm{mg} / \mathrm{dL}$ because of the very high risk for CVD in these patients, particularly patients on dialysis. In the "Evidence-based Clinical Practice Guidelines for the treatment of CDK 2009" ${ }^{10)}$, JSN proposed a recommendation to control LDL-C below $120 \mathrm{mg} / \mathrm{dL}$ in patients with CKD. Also, LDL-C below $100 \mathrm{mg} / \mathrm{dL}$ is recommended if possible. Recently, JSDT published clinical practice guidelines regarding the evaluation and treatment of cardiovascular complications in dialysis patients ${ }^{86)}$. The JSDT guidelines recommend controlling LDL-C below $120 \mathrm{mg} / \mathrm{dL}$ for primary prevention and below $100 \mathrm{mg} / \mathrm{dL}$ for secondary prevention. Alternative goals are non-HDL-C below $150 \mathrm{mg} / \mathrm{dL}$ and $130 \mathrm{mg} / \mathrm{dL}$ using non-fasting blood samples. No recommendations are mentioned on TG or HDL-C in the above four guidelines for CKD patients. The European Society of Cardiology (ESC) and the European Atherosclerosis Society (EAS) have published guidelines for the management of dyslipidemia, and the ESC/DAS guidelines ${ }^{87)}$ recommend achieving LDL-C $<1.8 \mathrm{mmol} / \mathrm{L}(<70 \mathrm{mg} / \mathrm{dL})$ in patients with CKD stage $2-4$ based on the recognition that CKD is CAD risk equivalent.

\section{Conclusions}

The risk of death from CVD is elevated in patients with $\mathrm{CKD}$, and the risk is higher in more advanced stages of CKD. The impact of CKD on incident CVD is as large as that of type 2 diabetes 
Table 7. Comparison of target levels of serum lipids for patients with CKD proposed by published clinical practice guidelines

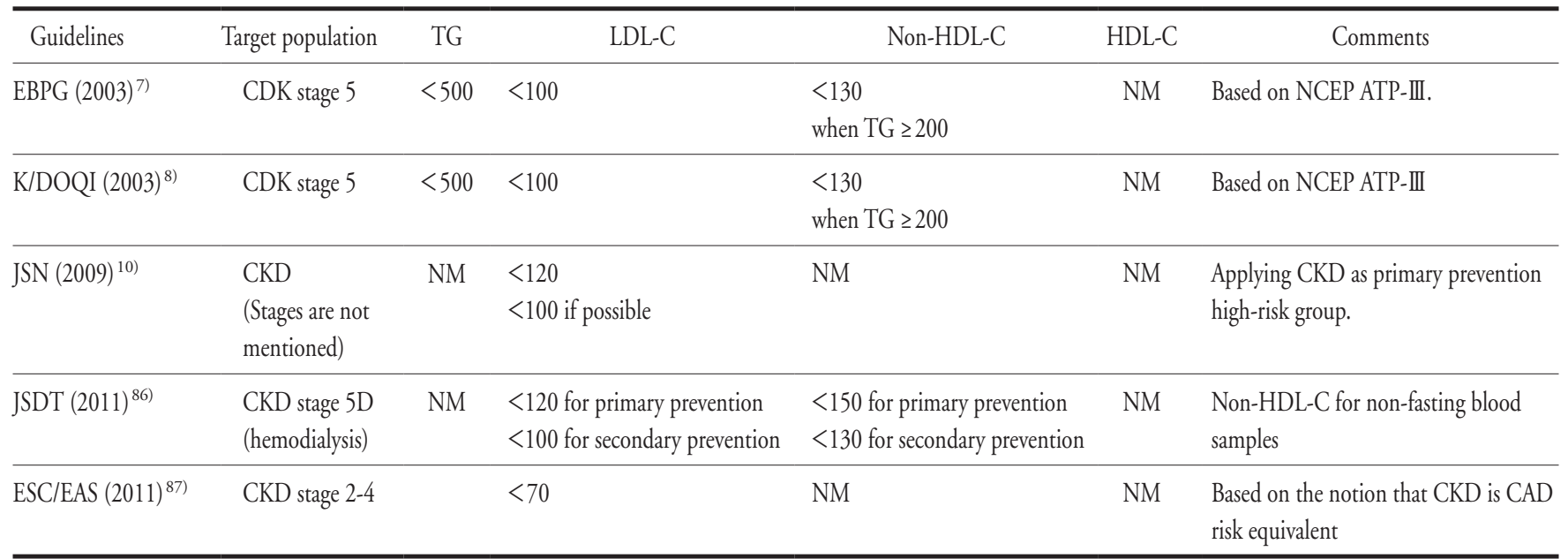

The table gives the target populations and target levels of serum lipid levels recommended by the clinical practice guidelines for CKD patients. Abbreviations: TG, triglycerides; LDL-C, low-density lipoprotein cholesterol; Non-HDL-C, non-high-density lipoprotein cholesterol; HDL-C, high-density lipoprotein cholesterol; EBPG, European Best Practice Guidelines; K/DOQI, Kidney Disease Outcome Quality Initiative; JSN, Japanese Society of Nephrology; JSDT, Japanese Society for Dialysis Therapy; NM, not mentioned.

mellitus and pre-existing ischemic heart disease. Patients with CKD often have risk factors of death from CVD including both traditional and non-traditional risk factors. Among the traditional risk factors, dyslipidemia is modifiable. Because TG-rich lipoproteins (VLDL and IDL) are increased in CKD, particularly in advanced stages, non-HDL-C may be a better index for dyslipidemia than LDL-C in this population. Lipid-lowering treatment with statins is effective in reducing the risk for CVD in early stages of CKD, whereas the benefit of such medication may be limited to those with an elevated level of LDL-C in patients with CKD stage 5D.

Thus, in our opinion, CKD should be regarded as an important subgroup of patients at high risk for CVD. The target levels for LDL-C or non-HDL-C should be set lower in CKD as a high-risk population. Further information is needed to develop individualized recommendations for patients with different stages of CKD.

\section{References}

1) Japanese Society for Dialysis Therapy: An overview of regular dialysis treatment in Japan as of Dec. 31, 2009. Tokyo2010

2) Foley RN, Parfrey PS, Sarnak MJ: Clinical epidemiology of cardiovascular disease in chronic renal disease. Am J Kidney Dis, 1998; 32: S112-119

3) Lindner A, Charra B, Sherrard DJ, Scribner BH: Accelerated atherosclerosis in prolonged maintenance hemodialysis. N Engl J Med, 1974; 290: 697-701
4) Hillege HL, Fidler V, Diercks GF, van Gilst WH, de Zeeuw D, van Veldhuisen DJ, Gans RO, Janssen WM, Grobbee DE, de Jong PE: Urinary albumin excretion predicts cardiovascular and noncardiovascular mortality in general population. Circulation, 2002; 106: 1777-1782

5) Manjunath G, Tighiouart H, Ibrahim H, MacLeod B, Salem DN, Griffith JL, Coresh J, Levey AS, Sarnak MJ: Level of kidney function as a risk factor for atherosclerotic cardiovascular outcomes in the community. J Am Coll Cardiol; 2003: 41; 47-55

6) Sarnak MJ, Levey AS, Schoolwerth AC, Coresh J, Culleton B, Hamm LL, McCullough PA, Kasiske BL, Kelepouris E, Klag MJ, Parfrey P, Pfeffer M, Raij L, Spinosa DJ, Wilson PW: Kidney disease as a risk factor for development of cardiovascular disease: a statement from the American Heart Association Councils on Kidney in Cardiovascular Disease, High Blood Pressure Research, Clinical Cardiology, and Epidemiology and Prevention. Circulation, 2003; 108: 2154-2169

7) European best practice guidelines for haemodialysis (part I). Section VII. Vascular disease and risk factors. Nephrol Dial Transplant, 2002; 17 (Suppl 7): 88-109

8) K/DOQI clinical practice guidelines for management of dyslipidemias in patients with kidney disease. Am J Kidney Dis, 2003; 41: I-IV, S1-91

9) Clinical Practice Guidebook for Diagnosis and Treatment of Chronic Kidney Disease 2007. Tokyo: Tokyo Igaku Sha; 2007 (in Japanese)

10) Japanese Society of Nephrology: Evidence-based Clinical Practice Guidelines for the treatment of CDK. Tokyo: Tokyo Igakusha; 2009 (in Japanese)

11) Teramoto T, Sasaki J, Ueshima H, Egusa G, Kinoshita M, Shimamoto K, Daida H, Biro S, Hirobe K, Funahashi T, Yokote K, Yokode M: Executive summary of Japan Atherosclerosis Society (JAS) guideline for diagnosis and pre- 
vention of atherosclerotic cardiovascular diseases for Japanese. J Atheroscler Thromb, 2007; 14: 45-50

12) K/DOQI clinical practice guidelines for chronic kidney disease: evaluation, classification, and stratification. Am J Kidney Dis, 2002; 39: S1-266

13) Matsuo S, Imai E, Horio M, Yasuda Y, Tomita K, Nitta K, Yamagata K, Tomino Y, Yokoyama H, Hishida A: Revised equations for estimated GFR from serum creatinine in Japan. Am J Kidney Dis, 2009; 53: 982-992

14) Levey AS, Eckardt KU, Tsukamoto Y, Levin A, Coresh J, Rossert J, De Zeeuw D, Hostetter TH, Lameire N, Eknoyan G: Definition and classification of chronic kidney disease: a position statement from Kidney Disease: Improving Global Outcomes (KDIGO). Kidney Int, 2005; 67: 2089-2100

15) Levey AS, de Jong PE, Coresh J, El Nahas M, Astor BC, Matsushita K, Gansevoort RT, Kasiske BL, Eckardt KU: The definition, classification, and prognosis of chronic kidney disease: a KDIGO Controversies Conference report. Kidney Int, 2011; 80: 17-28

16) Kannel WB, Stampfer MJ, Castelli WP, Verter J: The prognostic significance of proteinuria: the Framingham study. Am Heart J, 1984; 108: 1347-1352

17) Damsgaard EM, Froland A, Jorgensen OD, Mogensen CE: Microalbuminuria as predictor of increased mortality in elderly people. Bmj, 1990; 300: 297-300

18) Wachtell K, Ibsen H, Olsen MH, Borch-Johnsen K, Lindholm LH, Mogensen CE, Dahlof B, Devereux RB, Beevers G, de Faire U, Fyhrquist F, Julius S, Kjeldsen SE, Kristianson K, Lederballe-Pedersen O, Nieminen MS, Okin PM, Omvik P, Oparil S, Wedel H, Snapinn SM, Aurup P: Albuminuria and cardiovascular risk in hypertensive patients with left ventricular hypertrophy: the LIFE study. Ann Intern Med, 2003; 139: 901-906

19) Klausen K, Borch-Johnsen K, Feldt-Rasmussen B, Jensen G, Clausen P, Scharling H, Appleyard M, Jensen JS: Very low levels of microalbuminuria are associated with increased risk of coronary heart disease and death independently of renal function, hypertension, and diabetes. Circulation, 2004; 110: 32-35

20) Keith DS, Nichols GA, Gullion CM, Brown JB, Smith DH: Longitudinal follow-up and outcomes among a population with chronic kidney disease in a large managed care organization. Arch Intern Med, 2004; 164: 659-663

21) K/DOQI clinical practice guidelines on hypertension and antihypertensive agents in chronic kidney disease. Am J Kidney Dis, 2004; 43: S1-290

22) Brugts JJ, Knetsch AM, Mattace-Raso FU, Hofman A, Witteman JC: Renal function and risk of myocardial infarction in an elderly population: the Rotterdam Study. Arch Intern Med, 2005; 165: 2659-2665

23) Kottgen A, Russell SD, Loehr LR, Crainiceanu CM, Rosamond WD, Chang PP, Chambless LE, Coresh J: Reduced kidney function as a risk factor for incident heart failure: the atherosclerosis risk in communities (ARIC) study. J Am Soc Nephrol, 2007; 18: 1307-1315

24) Weiner DE, Tighiouart H, Levey AS, Elsayed E, Griffith JL, Salem DN, Sarnak MJ: Lowest systolic blood pressure is associated with stroke in stages 3 to 4 chronic kidney disease. J Am Soc Nephrol, 2007; 18: 960-966
25) Ninomiya T, Perkovic V, de Galan BE, Zoungas S, Pillai A, Jardine M, Patel A, Cass A, Neal B, Poulter N, Mogensen CE, Cooper M, Marre M, Williams B, Hamet P, Mancia G, Woodward M, Macmahon S, Chalmers J: Albuminuria and Kidney Function Independently Predict Cardiovascular and Renal Outcomes in Diabetes. J Am Soc Nephrol, 2009

26) Ninomiya T, Kiyohara $Y$, Kubo M, Tanizaki $Y$, Doi $Y$, Okubo K, Wakugawa Y, Hata J, Oishi Y, Shikata K, Yonemoto K, Hirakata H, Iida M: Chronic kidney disease and cardiovascular disease in a general Japanese population: the Hisayama Study. Kidney Int, 2005; 68: 228-236

27) Kokubo Y, Nakamura S, Okamura T, Yoshimasa Y, Makino $\mathrm{H}$, Watanabe $\mathrm{M}$, Higashiyama A, Kamide $\mathrm{K}$, Kawanishi K, Okayama A, Kawano Y: Relationship between blood pressure category and incidence of stroke and myocardial infarction in an urban Japanese population with and without chronic kidney disease: the Suita Study. Stroke, 2009; 40: 2674-2679

28) Ninomiya T, Kiyohara Y, Tokuda Y, Doi Y, Arima H, Harada A, Ohashi Y, Ueshima H: Impact of kidney disease and blood pressure on the development of cardiovascular disease: an overview from the Japan Arteriosclerosis Longitudinal Study. Circulation, 2008; 118: 2694-2701

29) Nakamura K, Okamura T, Hayakawa T, Kadowaki T, Kita Y, Ohnishi H, Saitoh S, Sakata K, Okayama A, Ueshima $\mathrm{H}$ : Chronic kidney disease is a risk factor for cardiovascular death in a community-based population in Japan: NIPPON DATA90. Circ J, 2006; 70: 954-959

30) Irie F, Iso H, Sairenchi T, Fukasawa N, Yamagishi K, Ikehara S, Kanashiki M, Saito Y, Ota H, Nose T: The relationships of proteinuria, serum creatinine, glomerular filtration rate with cardiovascular disease mortality in Japanese general population. Kidney Int, 2006; 69: 12641271

31) Hatta T, Nishimura $S$, Nishimura T: Prognostic risk stratification of myocardial ischaemia evaluated by gated myocardial perfusion SPECT in patients with chronic kidney disease. Eur J Nucl Med Mol Imaging, 2009; 36: 18351841

32) Yamasaki $Y$, Nakajima $K$, Kusuoka $H$, Izumi T, Kashiwagi A, Kawamori R, Shimamoto K, Yamada N, Nishimura T: Prognostic value of gated myocardial perfusion imaging for asymptomatic patients with type 2 diabetes: the J-ACCESS 2 investigation. Diabetes Care, 2010; 33: 2320-2326

33) Matsushita K, van der Velde M, Astor BC, Woodward M, Levey AS, de Jong PE, Coresh J, Gansevoort RT: Association of estimated glomerular filtration rate and albuminuria with all-cause and cardiovascular mortality in general population cohorts: a collaborative meta-analysis. Lancet, 2010; 375: 2073-2081

34) Yasuno $S$, Ueshima K, Oba K, Fujimoto A, Ogihara T, Saruta T, Nakao K: Clinical significance of left ventricular hypertrophy and changes in left ventricular mass in highrisk hypertensive patients: a subanalysis of the Candesartan Antihypertensive Survival Evaluation in Japan trial. J Hypertens, 2009; 27: 1705-1712

35) Nishizawa Y, Shoji T: Does dialysis treatment promote atherosclerosis? . Jap J Clin Dial (Rinsho Toseki), 1996; 
12: 1133-1144 (in Japanese)

36) Japanese Society for Dialysis Therapy: An overview of regular dialysis treatment in Japan as of Dec.31, 2005 (CDROM version). Tokyo: Japanese Society for Dialysis Therapy; 2006 (in Japanese)

37) Ministry of Health, Labour and Welfare. Japanese Population Dynamics in 2005. http://www.mhlw.go.jp/toukei/ saikin/hw/jinkou/suikei05/. Accessed May 3, 2011(in Japanese): Statistical Bureau, Ministry of Internal Affairs and Communications, Japan. The national census as of Oct 1, 2005. http://www.mhlw.go.jp/toukei/saikin/hw/ jinkou/suikei05/index.html. Accessed May 3, 2011 (in Japanese)

38) Kronenberg F: Dyslipidemia and nephrotic syndrome: recent advances. J Ren Nutr, 2005; 15: 195-203

39) de Mendoza SG, Kashyap ML, Chen CY, Lutmer RF: High density lipoproteinuria in nephrotic syndrome. Metabolism, 1976; 25: 1143-1149

40) Wanner C, Quaschning T: Dyslipidemia and renal disease: pathogenesis and clinical consequences. Curr Opin Nephrol Hypertens, 2001; 10: 195-201

41) Ikewaki K, Schaefer JR, Frischmann ME, Okubo K, Hosoya T, Mochizuki S, Dieplinger B, Trenkwalder E, Schweer H, Kronenberg F, Koenig P, Dieplinger H: Delayed in vivo catabolism of intermediate-density lipoprotein and low-density lipoprotein in hemodialysis patients as potential cause of premature atherosclerosis. Arterioscler Thromb Vasc Biol, 2005; 25: 2615-2622

42) Shoji T, Nishizawa Y, Nishitani H, Yamakawa M, Morii $\mathrm{H}$ : Impaired metabolism of high density lipoprotein in uremic patients. Kidney Int, 1992; 41: 1653-1661

43) Shoji T, Nishizawa Y, Nishitani H, Yamakawa M, Morii $\mathrm{H}$ : Roles of hypoalbuminemia and lipoprotein lipase on hyperlipoproteinemia in continuous ambulatory peritoneal dialysis. Metabolism, 1991; 40: 1002-1008

44) Shoji $T$, Ishimura $E$, Inaba $M$, Tabata $T$, Nishizawa $Y$ : Atherogenic lipoproteins in end-stage renal disease. Am J Kidney Dis, 2001; 38: S30-33

45) Oi K, Hirano T, Sakai S, Kawaguchi Y, Hosoya T: Role of hepatic lipase in intermediate-density lipoprotein and small, dense low-density lipoprotein formation in hemodialysis patients. Kidney Int Suppl, 1999; 71: S227-228

46) Shoji T, Emoto M, Kawagishi T, Kimoto E, Yamada A, Tabata T, Ishimura E, Inaba M, Okuno Y, Nishizawa Y: Atherogenic lipoprotein changes in diabetic nephropathy. Atherosclerosis, 2001; 156: 425-433

47) Kimoto E, Shoji T, Emoto M, Miki T, Tabata T, Okuno Y, Ishimura $\mathrm{E}$, Inaba M, Nishizawa Y: Effect of diabetes on uremic dyslipidemia. J Atheroscler Thromb, 2002; 9: 305-313

48) Joki N, Hase H, Nakamura R, Yamaguchi T: Onset of coronary artery disease prior to initiation of haemodialysis in patients with end-stage renal disease. Nephrol Dial Transplant, 1997; 12: 718-723

49) Ohtake T, Kobayashi $S$, Moriya $H$, Negishi K, Okamoto K, Maesato K, Saito S: High prevalence of occult coronary artery stenosis in patients with chronic kidney disease at the initiation of renal replacement therapy: an angiographic examination. J Am Soc Nephrol, 2005; 16: 1141-1148
50) Araki T, Emoto M, Teramura M, Yokoyama H, Mori K, Hatsuda S, Maeno T, Shinohara K, Koyama H, Shoji T, Inaba M, Nishizawa Y: Effect of adiponectin on carotid arterial stiffness in type 2 diabetic patients treated with pioglitazone and metformin. Metabolism, 2006; 55: 9961001

51) Kawagishi T, Nishizawa $Y$, Konishi T, Kawasaki K, Emoto M, Shoji T, Tabata T, Inoue T, Morii H: High-resolution B-mode ultrasonography in evaluation of atherosclerosis in uremia. Kidney Int, 1995; 48: 820-826

52) Shoji T, Emoto M, Tabata T, Kimoto E, Shinohara K, Maekawa K, Kawagishi T, Tahara H, Ishimura E, Nishizawa Y: Advanced atherosclerosis in predialysis patients with chronic renal failure. Kidney Int, 2002; 61: 2187-2192

53) Shoji T, Nishizawa Y, Kawagishi T, Kawasaki K, Taniwaki $\mathrm{H}$, Tabata T, Inoue T, Morii H: Intermediate-density lipoprotein as an independent risk factor for aortic atherosclerosis in hemodialysis patients. J Am Soc Nephrol, 1998; 9: 1277-1284

54) Shinohara K, Shoji T, Tsujimoto $Y$, Kimoto E, Tahara H, Koyama H, Emoto M, Ishimura E, Miki T, Tabata T, Nishizawa Y: Arterial stiffness in predialysis patients with uremia. Kidney Int, 2004; 65: 936-943

55) Rigatto C, Levin A, House AA, Barrett B, Carlisle E, Fine A: Atheroma progression in chronic kidney disease. Clin J Am Soc Nephrol, 2009; 4: 291-298

56) Fukumoto M, Shoji T, Emoto M, Kawagishi T, Okuno Y, Nishizawa Y: Antibodies against oxidized LDL and carotid artery intima-media thickness in a healthy population. Arterioscler Thromb Vasc Biol, 2000; 20: 703-707

57) Kimoto E, Shoji T, Shinohara K, Hatsuda S, Mori K, Fukumoto S, Koyama H, Emoto M, Okuno Y, Nishizawa Y: Regional arterial stiffness in patients with type 2 diabetes and chronic kidney disease. J Am Soc Nephrol, 2006; 17: 2245-2252

58) Lowrie EG, Lew NL: Death risk in hemodialysis patients: the predictive value of commonly measured variables and an evaluation of death rate differences between facilities. Am J Kidney Dis, 1990; 15: 458-482

59) Degoulet P, Legrain M, Reach I, Aime F, Devries C, Rojas P, Jacobs C: Mortality risk factors in patients treated by chronic hemodialysis. Report of the Diaphane collaborative study. Nephron, 1982; 31: 103-110

60) Kalantar-Zadeh K, Block G, Humphreys MH, Kopple JD: Reverse epidemiology of cardiovascular risk factors in maintenance dialysis patients. Kidney Int, 2003; 63: 793808

61) Nishizawa Y, Shoji T, Ishimura E, Inaba M, Morii H: Paradox of risk factors for cardiovascular mortality in uremia: is a higher cholesterol level better for atherosclerosis in uremia? Am J Kidney Dis, 2001; 38: S4-7

62) Shoji T, Nishizawa Y: Chronic kidney disease as a metabolic syndrome with malnutrition--need for strict control of risk factors. Intern Med, 2005; 44: 179-187

63) Shoji T, Masakane I, Watanabe Y, Iseki K, Tsubakihara Y: Elevated Non-high-density Lipoprotein Cholesterol (Non-HDL-C) Predicts Atherosclerotic Cardiovascular Events in Hemodialysis Patients. Clin J Am Soc Nephrol, 2011; 6: 1112-1120 
64) Stenvinkel P, Heimburger O, Lindholm B, Kaysen GA, Bergstrom J: Are there two types of malnutrition in chronic renal failure? Evidence for relationships between malnutrition, inflammation and atherosclerosis (MIA syndrome). Nephrol Dial Transplant, 2000; 15: 953-960

65) MRC/BHF Heart Protection Study of cholesterol lowering with simvastatin in 20,536 high-risk individuals: a randomised placebo-controlled trial. Lancet, 2002; 360: 7-22

66) Sever PS, Dahlof B, Poulter NR, Wedel H, Beevers G, Caulfield M, Collins R, Kjeldsen SE, Kristinsson A, McInnes GT, Mehlsen J, Nieminen M, O’Brien E, Ostergren J: Prevention of coronary and stroke events with atorvastatin in hypertensive patients who have average or lower-than-average cholesterol concentrations, in the Anglo-Scandinavian Cardiac Outcomes Trial--Lipid Lowering Arm (ASCOT-LLA): a multicentre randomised controlled trial. Lancet, 2003; 361: 1149-1158

67) Tonelli M, Isles C, Curhan GC, Tonkin A, Pfeffer MA, Shepherd J, Sacks FM, Furberg C, Cobbe SM, Simes J, Craven T, West M: Effect of pravastatin on cardiovascular events in people with chronic kidney disease. Circulation, 2004; 110: 1557-1563

68) Holdaas H, Wanner C, Abletshauser C, Gimpelewicz C, Isaacsohn J: The effect of fluvastatin on cardiac outcomes in patients with moderate to severe renal insufficiency: a pooled analysis of double-blind, randomized trials. Int J Cardiol, 2007; 117: 64-74

69) Nakamura H, Mizuno K, Ohashi Y, Yoshida T, Hirao K, Uchida Y: Pravastatin and cardiovascular risk in moderate chronic kidney disease. Atherosclerosis, 2009; 206: 512517

70) Colhoun HM, Betteridge DJ, Durrington PN, Hitman GA, Neil HA, Livingstone SJ, Charlton-Menys V, DeMicco DA, Fuller JH: Effects of atorvastatin on kidney outcomes and cardiovascular disease in patients with diabetes: an analysis from the Collaborative Atorvastatin Diabetes Study (CARDS). Am J Kidney Dis, 2009; 54: 810-819

71) Wanner C, Krane V, Marz W, Olschewski M, Mann JF, Ruf G, Ritz E: Atorvastatin in patients with type 2 diabetes mellitus undergoing hemodialysis. N Engl J Med, 2005; 353: 238-248

72) Fellstrom BC, Jardine AG, Schmieder RE, Holdaas H, Bannister K, Beutler J, Chae DW, Chevaile A, Cobbe SM, Gronhagen-Riska C, De Lima JJ, Lins R, Mayer G, McMahon AW, Parving HH, Remuzzi G, Samuelsson O, Sonkodi S, Sci D, Suleymanlar G, Tsakiris D, Tesar V, Todorov V, Wiecek A, Wuthrich RP, Gottlow M, Johnsson E, Zannad F: Rosuvastatin and cardiovascular events in patients undergoing hemodialysis. N Engl J Med, 2009; 360: 1395-1407

73) März W, Genser B, Drechsler C, Krane V, Grammer TB, Ritz E, Stojakovic T, Scharnagl H, Winkler K, Holme I, Holdaas H, Wanner C: Atorvastatin and Low-Density Lipoprotein Cholesterol in Type 2 Diabetes Mellitus Patients on Hemodialysis. Clin J Am Soc Nephrol, 2011; 6: $1316-1325$

74) Baigent C, Landray MJ, Reith C, Emberson J, Wheeler DC, Tomson C, Wanner C, Krane V, Cass A, Craig J,
Neal B, Jiang L, Hooi LS, Levin A, Agodoa L, Gaziano M, Kasiske B, Walker R, Massy ZA, Feldt-Rasmussen B, Krairittichai U, Ophascharoensuk V, Fellstrom B, Holdaas $\mathrm{H}$, Tesar V, Wiecek A, Grobbee D, de Zeeuw D, Gronhagen-Riska C, Dasgupta T, Lewis D, Herrington W, Mafham M, Majoni W, Wallendszus K, Grimm R, Pedersen T, Tobert J, Armitage J, Baxter A, Bray C, Chen Y, Chen Z, Hill M, Knott C, Parish S, Simpson D, Sleight P, Young A, Collins R: The effects of lowering LDL cholesterol with simvastatin plus ezetimibe in patients with chronic kidney disease (Study of Heart and Renal Protection): a randomised placebo-controlled trial. Lancet, 2011; 377: 2181-2192

75) Schaeffner ES, Kurth T, Curhan GC, Glynn RJ, Rexrode KM, Baigent C, Buring JE, Gaziano JM: Cholesterol and the risk of renal dysfunction in apparently healthy men. J Am Soc Nephrol, 2003; 14: 2084-2091

76) Shoji T, Nishizawa Y, Toyokawa A, Kawagishi T, Okuno Y, Morii H: Decreased albuminuria by pravastatin in hyperlipidemic diabetics. Nephron, 1991; 59: 664-665

77) Nakamura T, Ushiyama C, Hirokawa K, Osada S, Inoue T, Shimada N, Koide H: Effect of cerivastatin on proteinuria and urinary podocytes in patients with chronic glomerulonephritis. Nephrol Dial Transplant, 2002; 17: 798802

78) Sandhu S, Wiebe N, Fried LF, Tonelli M: Statins for improving renal outcomes: a meta-analysis. J Am Soc Nephrol, 2006; 17: 2006-2016

79) Nakamura T, Kawagoe Y, Ogawa H, Ueda Y, Hara M, Shimada N, Ebihara I, Koide H: Effect of low-density lipoprotein apheresis on urinary protein and podocyte excretion in patients with nephrotic syndrome due to diabetic nephropathy. Am J Kidney Dis, 2005; 45: 48-53

80) Athyros VG, Mikhailidis DP, Papageorgiou AA, Symeonidis AN, Pehlivanidis AN, Bouloukos VI, Elisaf M: The effect of statins versus untreated dyslipidaemia on renal function in patients with coronary heart disease. A subgroup analysis of the Greek atorvastatin and coronary heart disease evaluation (GREACE) study. J Clin Pathol, 2004; $57:$ 728-734

81) Shepherd J, Kastelein JJ, Bittner V, Deedwania P, Breazna A, Dobson S, Wilson DJ, Zuckerman A, Wenger NK: Effect of intensive lipid lowering with atorvastatin on renal function in patients with coronary heart disease: the Treating to New Targets (TNT) study. Clin J Am Soc Nephrol, 2007; 2: 1131-1139

82) Kimura K, Shimano H, Yokote K, Urashima M, Teramoto T: Effects of pitavastatin (LIVALO tablet) on the estimated glomerular filtration rate (eGFR) in hypercholesterolemic patients with chronic kidney disease. Subanalysis of the LIVALO Effectiveness and Safety (LIVES) Study. J Atheroscler Thromb, 2010; 17: 601-609

83) Endo K, Miyashita Y, Sasaki H, Ohira M, Saiki A, Koide N, Otsuka M, Oyama T, Takeyoshi M, Ito Y, Shirai K: Probucol delays progression of diabetic nephropathy. Diabetes Res Clin Pract, 2006; 71: 156-163

84) Keech A, Simes RJ, Barter P, Best J, Scott R, Taskinen MR, Forder P, Pillai A, Davis T, Glasziou P, Drury P, Kesaniemi YA, Sullivan D, Hunt D, Colman P, d'Emden M, Whiting M, Ehnholm C, Laakso M: Effects of long-term 
fenofibrate therapy on cardiovascular events in 9795 people with type 2 diabetes mellitus (the FIELD study): randomised controlled trial. Lancet, 2005; 366: 1849-1861

85) Executive Summary of The Third Report of The National Cholesterol Education Program (NCEP) Expert Panel on Detection, Evaluation, And Treatment of High Blood Cholesterol In Adults (Adult Treatment Panel III). JAMA, 2001; 285: 2486-2497

86) Japanese Society for Dialysis Therapy: Clinical Guidelines for the Evaluation and the Treatment of Cardiovascular Complications in Hemodialysis Patients. J Jap Soc Dial Ther, 2011; 44: 337-425 (in Japanese)

87) Reiner Z, Catapano AL, De Backer G, Graham I, Taskinen MR, Wiklund O, Agewall S, Alegria E, Chapman MJ, Durrington P, Erdine S, Halcox J, Hobbs R, Kjekshus J, Filardi PP, Riccardi G, Storey RF, Wood D, Bax J, Vahanian A, Auricchio A, Baumgartner H, Ceconi C, Dean V, Deaton C, Fagard R, Filippatos G, Funck-Brentano C, Hasdai D, Hoes A, Kearney P, Knuuti J, Kolh P,
McDonagh T, Moulin C, Poldermans D, Popescu BA, Sechtem U, Sirnes PA, Tendera M, Torbicki A, Vardas P, Widimsky P, Windecker S, Berkenboom G, De Graaf J, Descamps O, Gotcheva N, Griffith K, Guida GF, Gulec S, Henkin Y, Huber K, Kesaniemi YA, Lekakis J, Manolis AJ, Marques-Vidal P, Masana L, McMurray J, Mendes M, Pagava Z, Pedersen T, Prescott E, Rato Q, Rosano G, Sans S, Stalenhoef A, Tokgozoglu L, Viigimaa M, Wittekoek ME, Zamorano JL: ESC/EAS Guidelines for the management of dyslipidaemias: The Task Force for the management of dyslipidaemias of the European Society of Cardiology (ESC) and the European Atherosclerosis Society (EAS). Eur Heart J, 2011; 32: 1769-1818

88) Kendrick J, Shlipak MG, Targher G, Cook T, Lindenfeld J, Chonchol M: Effect of lovastatin on primary prevention of cardiovascular events in mild CKD and kidney function loss: a post hoc analysis of the Air Force/Texas Coronary Atherosclerosis Prevention Study. Am J Kidney Dis, 2010; 55: $42-49$ 